\title{
Restriction fragment length polymorphism of the insulin gene region in Japanese diabetic and non-diabetic subjects
}

\author{
T.Awata, Y.Shibasaki, H. Hirai, T. Okabe, Y.Kanazawa and F. Takaku \\ The Third Department of Internal Medicine, Faculty of Medicine, University of Tokyo, Tokyo, Japan
}

Summary. A polymorphic locus flanking the $5^{\prime}$ end of the insulin gene was studied in 154 unrelated Japanese diabetic and nondiabetic subjects. A predominance of the small allele was found with the following frequency: of 64 nondiabetic subjects, only 3 of 128 alleles were of the large class ( $2 \%)$; none of 78 alleles were of the large class in 39 Type 1 (insulin-dependent) diabetic subjects, and 4 of 102 alleles (4\%) were of the large class in 51 Type 2 (non-insulin-dependent) diabetic subjects. The very low frequency of large allele may relate to the lower prevalence of atherosclerosis in Japanese. However, this possibility requires further examination.

Key words: Japanese, Type 1 diabetes, Type 2 diabetes, restriction length polymorphism, insulin gene, atherosclerosis.
A polymorphic locus flanking the $5^{\prime}$ end of the human insulin gene has been described in Caucasians [1-7], American Blacks $[4,5,8]$, Pima Indians $[4,9]$, natives of the South Pacific Islands [10] and some other racial groups [5]. This polymorphism, located about $500 \mathrm{bp}$ before the start of the insulin gene, is detected by means of restriction endonucleases and is due to insertions or deletions of repeating oligonucleotides within the region [11].

In Caucasians, the small allele relates to Type 1 (insulin-dependent) diabetes $[5,7]$. An association of the large allele with atherosclerosis has been reported [12, 13]. A possible association of the large allele and Type 2 (non-insulin-dependent) diabetes has also been reported $[2,3,4]$; subsequent studies have suggested that there is no association between the large allele and Type 2 diabetes in Caucasians [5, 6, 13], American Blacks [8], Pima Indians [9] and natives of the South Pacific Islands [10].

However, these data did not disclose the significance of this polymorphism in the pathogenesis and/or pathophysiology of diabetes mellitus. It is well known that Japanese diabetes mellitus is different from that of Caucasians in several respects, such as the low prevalence of Type 1 diabetes [14] and the low incidence of macroangiopathy in Type 2 diabetes [15]. The analysis of restriction length polymorphism of the insulin gene region in Japanese diabetic subjects might be very useful for elucidating the role of the polymorphism in diabetes mellitus.
Although Bell et al. [5] described the polymorphism of the insulin gene region in Asians (Chinese, Japanese and Korean heritage), the result was inconclusive due to the small sample size.

\section{Subjects and methods}

Peripheral blood leukocytes were obtained from 154 unrelated subjects (64 nondiabetic subjects, 39 Type 1 diabetic subjects, and 51 Type 2 diabetic subjects). All subjects came from Tokyo or prefectures near Tokyo, and were classified according to the criteria of the $\mathrm{Na}$ tional Diabetes Data Group [16].

High molecular weight DNA was prepared from the nuclei of peripheral leukocytes [17]. DNA was digested for $12-20 \mathrm{~h}$ with restriction endonuclease Sac I (Sst I). The digested DNA was electrophoresed on a agarose gel and transferred to a nitrocellulose filter [18]. The same samples were also analysed with Bgl I or Rsa I. The nitrocellulose filters were hybridized with ${ }^{32} \mathrm{P}$-labelled insulin gene probe, and the resulting hybrids were visualized by autoradiography. The probe used in this study was a $5^{\prime}$-flanking Bgl I-Bgl II fragment (Fig. 1) prepared from a human genomic clone. The fragment was labelled by nick translation to specific activities of at least $1 \times 10^{8} \mathrm{cpm} /$ $\mu \mathrm{g}$ DNA.

Differences were tested for significance by the $\chi^{2}$ analysis.

\section{Results}

Studies of restriction fragment length polymorphism of the insulin gene region revealed that there were three size classes of alleles of the following average sizes: class $1,570 \mathrm{bp}$; class $2,1320 \mathrm{bp}$; and class $3,2470 \mathrm{bp}$ [5]. 


\section{Rsa I}

\section{Sac I}

A B C

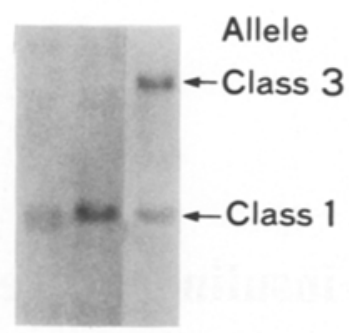

GENOTYPE $\quad 1 / 11 / 11 / 3$

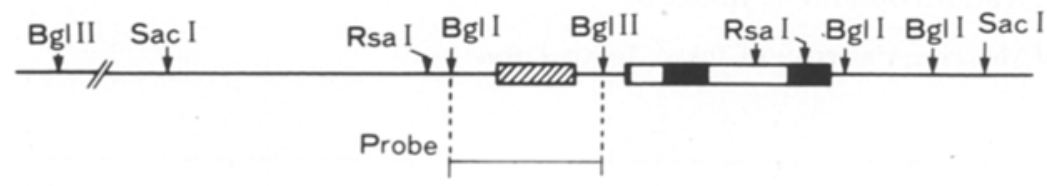

$1 / 11 / 11 / 3$

A B C

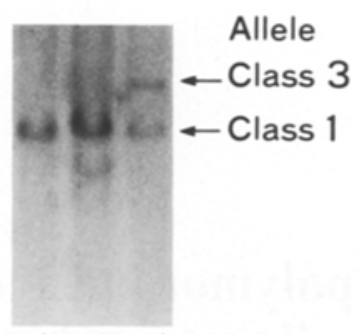

Fig. 1. Autoradiograms of insulin gene fragments (Rsa I or Sac I digestion). Tracks A, B and C are DNA samples from three subjects after digestion with restriction endonuclease Rsa I (left) and Sac I (right) studied by Southern blot hybridization. Below the autoradiograms is a restriction enzyme map of the human insulin gene and flanking region. Probe used in this study was $5^{\prime}$-flanking BglI-BglII fragment containing the polymorphic region (shadowed box)
We observed two major sizes of Sac I generated restriction fragments in Japanese; $5.5-6.3 \mathrm{~kb}$ and $7.6-8.3 \mathrm{~kb}$. The former is considered to be the class $1 \mathrm{al}-$ lele, while the latter is assumed to be the class 3 allele. The class 2 allele was not observed in this study. We verified these results by digesting with Bgl I or Rsa I (Fig. 1).

Genotypic and allelic frequencies of the 154 subjects are shown in Table 1. Only 7 individuals (three nondiabetic subjects, four with Type 2 diabetes) had genotype $1 / 3$. Those with genotype $1 / 3$ were not distinctly different in age, sex, body mass index, age at diagnosis, family history, $\mathrm{HbA1}$, plasma triglycerides and total cholesterol concentration from those with genotype $1 / 1$ (data not shown).

\section{Discussion}

We have found a strikingly lower frequency of larger alleles (class 2 or 3 ) in the Japanese population (both nondiabetic and diabetic subjects) compared with the data of Caucasians, American Blacks, Pima Indians and natives of the South Pacific Islands.

Bell et al. [5] showed an association of the class 1 allele with Type 1 diabetes in Caucasians, and Hitman et al. [7] verified and confirmed this association. If an increased frequency of class 1 alleles indicates more susceptibility to Type 1 diabetes, the very high frequency of the class 1 allele in the Japanese population is at variance with the very low prevalence of Type 1 diabetes in Japanese [14]. Other factors may be more closely related to the initiation of Type 1 diabetes. More detailed classification of class 1 alleles by using a different probe with another restriction endonuclease may be useful in solving this question.

The possible association of the large allele with atherosclerosis $[12,13]$, and the low frequency of the
Table 1. Genotype distribution and allelic frequencies at the polymorphic locus flanking the $5^{\prime}$ end of the human insulin gene in three diagnostic groups

\begin{tabular}{|c|c|c|c|c|c|}
\hline & \multicolumn{3}{|c|}{ Genotype } & \multicolumn{2}{|c|}{ Allele } \\
\hline & $1 / 1$ & $1 / 3$ & $3 / 3$ & 1 & 3 \\
\hline $\begin{array}{l}\text { Nondiabetic } \\
\text { subjects } \\
(n=64)\end{array}$ & $\begin{array}{c}61 \\
(95 \%)\end{array}$ & $\begin{array}{c}3 \\
(5 \%)\end{array}$ & $\begin{array}{c}0 \\
(0 \%)\end{array}$ & 0.98 & 0.02 \\
\hline $\begin{array}{l}\text { Type } 1 \text { diabetic } \\
\text { subjects } \\
(n=39)\end{array}$ & $\begin{array}{c}39 \\
(100 \%)\end{array}$ & $\begin{array}{c}0 \\
(0 \%)\end{array}$ & $\begin{array}{c}0 \\
(0 \%)\end{array}$ & 1.00 & 0.00 \\
\hline $\begin{array}{l}\text { Type } 2 \text { diabetic } \\
\text { subjects } \\
(n=51)\end{array}$ & $\begin{array}{c}47 \\
(92 \%)\end{array}$ & $\begin{array}{c}4 \\
(8 \%)\end{array}$ & $\begin{array}{c}0 \\
(0 \%)\end{array}$ & 0.96 & 0.04 \\
\hline
\end{tabular}

Statistics: Genotype $-p=$ NS. Allele $-p=$ NS.

large allele among Japanese, supports the observation that less macroangiopathy occurs in Japanese diabetic subjects than in Caucasians [15]; this may account for the lower prevalence of atherosclerosis among Japanese. However, this possibility requires further examination.

The very low frequency of class 3 alleles in the Japanese may make restriction fragment length polymorphism of the insulin gene region a weaker genetic marker than in other racial groups. However, the remarkable difference in allelic frequencies among the races is interesting in view of the genetic evolution of eukaryotic genes. It may be useful to analyse the relationship between these differences and the prevalence of specific diseases in these different races.

Acknowledgements. The insulin genomic clone used in this study was kindly donated by Dr. G.I. Bell, Chiron Corporation, Emeryville, California, USA. We thank Drs. Y. Iwamoto and T. Kuzuya, Department of Endocrinology and Metabolism, Jichi Medical School, Tochigiken, and Dr. S. Amemiya, Department of Pediatrics, Keio Uni- 
versity Medical School, Tokyo, for their help in the collection of cases. The authors would like to thank Professor Wilfred Y. Fujimoto, Department of Medicine, University of Washington, Seattle, Washington, USA, for reviewing our manuscript. This work was partly supported by Grant-in-Aid-Scientific-Research No. 59570472.

\section{References}

1. Bell GI, Karam JH, Rutter WJ (1981) A polymorphic DNA region adjacent to the $5^{\prime}$ end of the human insulin gene. Proc Natl Acad Sci USA 78: 5759-63

2. Rotwein P, Chyn R, Chirgwin J, Cordell B, Goodman HM, Permutt MA (1981) Polymorphism in the $5^{\prime}$-flanking region of the human insulin gene and its possible relation to type 2 diabetes. Science 213: $1117-20$

3. Owerbach D, Nerup J (1982) Restriction fragment length polymorphism of the insulin gene in diabetes mellitus. Diabetes 31 : $275-77$

4. Rotwein PS, Chirgwin J, Province M, Knowler WC, Pettit DJ, Cordell B, Goodman HM, Permutt MA (1983) Polymorphism in the $5^{\prime}$-flanking region of the human insulin gene: a genetic marker for non-insulin-dependent diabetes. N Engl J Med 308: 65-71

5. Bell GI, Horita S, Karam JH (1984) A polymorphic locus near the human insulin gene is associated with insulin-dependent diabetes mellitus. Diabetes 33: 176-83

6. Permutt MA, Rotwein P, Andreone T, Ward WK, Porte D (1985) Islet $\beta$-cell function and polymorphism in the $5^{\prime}$-flanking region of the human insulin gene. Diabetes 34: 311-14

7. Hitman GA, Tarn AC, Winter RM, Drummond V, Williams LG, Jowett NI, Bottazzo GF, Galton DJ (1985) Type 1 (insulin-dependent) diabetes and a highly variable locus close to the insulin gene on chromosome 11. Diabetologia 28: 218-22

8. Elbein S, Rotwein P, Permutt MA, Bell GI, Sanz N, Karam JH (1985) Lack of association of the polymorphic locus in the 5 -flanking region of the human insulin gene and diabetes in American Blacks. Diabetes 34: 433-39

9. Knowler WC, Pettitt DJ, Vasquez B, Rotwein PS, Anderone TL, Permutt MA (1984) Polymorphism in the $5^{\prime}$-flanking region of the human insulin gene: Relationship with noninsulin-dependent diabetes mellitus, glucose and insulin concentrations, and diabetes treatment in the Pima Indians. J Clin Invest 74: 2129 35
10. Serjeantson SW, Owerbach D, Zimmet P, Nerup J, Thoma K (1983) Genetics of diabetes in Nauru: Effects of foreign admixture. HLA antigens and the insulin -gene-linked polymorphism. Diabetologia 25: 13-17

11. Bell GI, Selby M, Rutter WJ (1982) The highly polymorphic region near the insulin gene is composed of simple tandemly repeating sequences. Nature 295:31-35

12. Owerbach D, Billesbølle P, Schroll M, Johansen K, Poulsen S, Nerup J (1982) Possible association between DNA sequences flanking the insulin gene and atherosclerosis. Lancet 2: 1291-93

13. Poulsen TM, Mortenson SA, Meinertz H, Owerbach D, Johansen K, Sørensen H, Nerup J (1984) DNA sequences flanking the insulin gene on chromosome 11 confer risk of atherosclerosis. Lancet $1: 250-252$

14. Kitagawa T, Fujita H, Hibi I, Aagenaes $\varnothing$, Laron $Z$, Laporte RE, Tajima N, Drash A (1984) A comparative study on the epidemiology of IDDM between Japan, Norway, Israel and the United States. Acta Paediatr Jpn 26: 275-81

15. Keen H (1985) The WHO Multinational Study of Vascular Disease in Diabetes: Prevalence of small vessel and large vessel disease in diabetic patients from 14 centres. Diabetologia 28: 615-640

16. National Diabetes Data Group (1979) Classification of diabetes mellitus and other categories of glucose intolerance. Diabetes 28: $1039-57$

17. Kunkel LM, Smith KD, Boyer SH, Borgaonkar DS, Wachtel SS, Miller OJ, Breg WR, Jones HW, Rary JM (1977) Analysis of human Y-chromosome-specific reiterated DNA in chromosome variants. Proc Natl Acad Sci USA 74: 1245-49

18. Southern EM (1975) Detection of specific sequences among DNA fragments separated by gel electrophoresis. J Mol Biol 98: 503-17

Received: 3 June 1985

and in revised form: 14 October 1985

Dr. Takuya Awata

The Third Department of Internal Medicine

Faculty of Medicine

University of Tokyo

Hongo, Bunkyo-ku

113 Tokyo

Japan 